\title{
MILK PRODUCTION UNITS CHARACTERIZED BY SANITARY, NUTRITIONAL AND INFRASTRUCTURE VARIABLES IN THE NORTHWEST, CENTER WESTERN AND SOUTHWEST MESOREGIONS OF RIO GRANDE DO SUL, BRAZIL
}

\author{
CARACTERIZAÇÃO DE UNIDADES DE PRODUÇÃO DE LEITE POR VARIÁVEIS \\ SANITÁRIAS, NUTRICIONAIS E DE INFRAESTRUTURA NAS MESORREGIÕES \\ NOROESTE, CENTRO OCIDENTAL E SUDOESTE DO RIO GRANDE DO SUL, \\ BRASIL
}

\section{Leonardo Ereno TADIELO ${ }^{1 *}$; Tainara BREMM ${ }^{2}$; Neliton Flores KASPER ${ }^{2}$; Caroline Alvarez da SILVA ${ }^{3}$; Taiani Ourique GAYER ${ }^{4}$; Juliano Gonçalves PEREIRA ${ }^{5}$; Vanessa Mendonça SOARES ${ }^{6}$; Deise Dalazen CASTAGNARA ${ }^{7}$}

1. Discente, Programa de Pós-Graduação em Medicina Veterinária, Universidade Estadual Paulista, UNESP, campus Botucatu, SP, Brasil; * leonardo.tadielo@unesp.br; 2. Médicos Veterinários, Universidade Federal do Pampa, UNIPAMPA, Uruguaiana, RS, Brasil; 3. Prof $^{(a)}$, Curso de Medicina Veterinária, Universidade da Região da Campanha, URCAMP, Alegrete, RS, Brasil; 4. Discente, Curso de Medicina Veterinária, Universidade Federal do Pampa, UNIPAMPA, Uruguaiana, RS, Brasil; 5. Prof. Dr. Departamento de Higiene

Veterinária e Saúde Pública, Faculdade de Medicina Veterinária e Zootecnia, Universidade Estadual Paulista, UNESP, campus Botucatu, SP, Brasil; 6. Programa de Pós-Graduação em Ciência Animal, PNPD/CAPES, Universidade Federal do Pampa, UNIPAMPA, Uruguaiana, RS, Brasil; 7. Prof ${ }^{(a)}$. Dr ${ }^{(a)}$., Curso de Medicina Veterinária, Universidade Federal do Pampa, UNIPAMPA, Uruguaiana, RS, Brasil

\begin{abstract}
Evaluating and characterizing production systems using farm characteristics allows the diagnosis of failing points. This diagnosis can be used to improve the productive and zootechnical indices. Little is known about the milk production systems in the state of Rio Grande do Sul, therefore, the aim of this study was to characterize the milk production systems of the Northwest, Center Western and Southwest mesoregions of Rio Grande do Sul, considering the infrastructure, milk handling, milk quantity and composition, and nutritional intake of the cattle. To conduct this study, 38 Milk Production Units (MPUs) registered at the Municipal Secretaries of Agriculture and Emater/Ascar-RS were randomly selected. After being randomly selected, the dairy farms were visited and a semi-structured guide questionnaire was applied and milk samples were collected from expansion tanks. The milk was analyzed for somatic cell counts (SCC) and total bacterial counts (TBC). Data were evaluated through principal component analysis and cluster analysis. Multivariate analysis allowed the investigated variables to be reduced into two main components (CP1 and CP2). These two showed eigenvalues greater than 1 (alpha $>1$ ) and together explained $55.05 \%$ of the characteristics variability of the 38 MPUs studied. CP1 contemplated productive capacity and factors related to nutritional management of the MPUs, interfering directly with reproductive performance. CP2 comprised milk handling and daily production. Using these main variables, the data set generated from the 38 MPUs studied were adjusted and classified into five groups (G1, G2, G3, G4, and G5). The characteristics of these groups differed statistically especially in infrastructure and nutritional management of the cattle. Due to their particularities, each of these five groups of MPUs requires strategic technical interventions to improve their productive indexes.
\end{abstract}

KEYWORDS: Management. Production Systems. Milk Quality.

\section{INTRODUCTION}

The milk activity is developed in milk production units (MPU) distributed throughout the Brazilian territory (WILLERS et al., 2014). These units have different characteristics regardless of the technological level adopted. The daily production and monthly remuneration play a fundamental role in the generation of jobs and income, moving the economy of the regions where they are inserted.
However, the activity is developed in the MPUs under production systems with a wide range of organizational, technological, and production scales (BODENMÜLLER FILHO et al., 2010; WINCK; THALER NETO, 2012). Thus, each productive system has peculiar characteristics, which directly affect the productive efficiency of the MPUs.

Rio Grande do Sul is the state in Brazil that produces the second largest volume of milk. In this 
state, the milk is produced in seven mesoregions which greatly differ in the annual volume produced (IBGE, 2014). The differences among the mesoregions are due to the number and size of the MPUs as well as the management adopted in them regarding food, nutritional, sanitary, reproductive, and zootechnical (GABBI et al, 2013). These aspects cause social and economic consequences in the insertion regions of the MPUs because they directly impact the milk production (BANKUTI; CALDAS, 2018; AGOSTINHO et al, 2019). Therefore, they are considered relevant in typological characterization studies of production systems (GABBI et al, 2013; BANKUTI; CALDAS, 2018).

To evaluate and characterize these production systems using characteristics of MPUs (Moura et al., 2013) allows their grouping and assists in the technical assistance performance (NERO et al., 2009) improving the zootechnical and productive indexes. It also allows detecting suitable solutions to identified problems (Portela Nunes et al., 2002), aiming adapted technical recommendations (BODENMÜLLER FILHO et al., 2010).

There are still few studies that contemplate this characterization in the Northwest, Center Western and Southwest mesoregions of Rio Grande do Sul (PORTELA et al, 2002; OLIVIO et al, 2005). The objective of this study was to typify the milk production systems of these regions, considering the farms' milking infrastructure and management, quantity and composition of milk, and nutritional conditions of the herds.

\section{MATERIAL AND METHODS}

The study was conducted in the Northwest, Center Western, and Southwest mesoregions of Rio Grande do Sul - Brazil. The regional climate is identified as wet mesothermal in the Köppen climate classification (Alvares et al., 2013). That is temperate, subtropical type, with great seasonal variation of temperatures (severe winters and hot summers).

For this study, 38 milk production units registered at the Municipal Secretaries of Agriculture and Emater/Ascar-RS were randomly selected. The daily sold volume of milk was used as a criterion for the representativeness of dairy producers in each city, who were ordered according to production. From this ordered database it was possible to randomly select the producers, where three producers were excluded and the following was selected. This step was repeated from the producers with the highest to the lowest daily volume of milk, characterizing a proportional and representative sampling.

After being randomly selected, the dairy farms were visited at a pre-established time and a semi-structured guide questionnaire was applied. This questionnaire elucidated information about the production systems, such as farm infrastructure, feed for animals, sanitary management of the mammary gland, milk management, and milk quality.

Milking of the animals was monitored during the visits to evaluate the hygienic-sanitary conditions visible on the premises, utensils, milking equipment, and milking operators. After finishing the milking, the milk storage tanks were sampled. The samples were kept cooled and conditioned in sterile $70 \mathrm{ml}$ collection vials until analysis. One of the vials contained Bronopol $\AA$ (2-bromonitropropane-1,3-diol) preservative for physicalchemical analysis and somatic cell counts (SCC) and another vial containing Azidiol $\AA$ preservative was used for total bacterial count analysis (TBC).

After being homogenized, the samples were sent to the Dairy Cattle Analysis Service (SARLE) of the University of Passo Fundo - RS. For this study, protein, fat, lactose, total solids (TS), and non-greasy solids (NGS) were analyzed by infrared (STANDARD., 2004). Somatic cell count (International IDF Standard, IDF 2006) and total bacterial count (International IDF Standard, IDF 2004) were analyzed by flow cytometry.

For statistical analyses, data were evaluated through multivariate analysis (factorial and cluster analysis), using the statistical software IBM SPSS Statistics 20.0. To consider the general characteristics of the farms, the values were calculated and the results were expressed as mean \pm standard deviation. For factor analysis, the Bartlett Test was used to evaluate the statistical criteria to reduce the number of variables, with a measure of sampling adequacy (MSA) greater than or equal to 0.6. The clusters (Hair et al., 2009; Lopes Junior et al., 2012) were analyzed by analysis of variance and the means were compared by the Tukey test considering a 5\% significance level.

\section{RESULTS AND DISCUSSION}

When considering the general characteristics of the cattle farms in the studied regions, it was verified that the farms have a total average area of $59.65 \pm 89.42$ hectares (ha), varying from 9 to 476 ha, with entirely familiar workmanship. The mean area used for forage 
production equals $23.78 \pm 38.56$ ha. This area is used for annual pasture production, composed of Sorghum bicolor (forage sorghum), Pennisetum glaucum (millet or sudan grass), and Avena strigosa (summer oats) and perennials such as Cynodon $s p$ (tifton 85), Brachiaria decumbens, and Brachiaria brizantha. In the summer, the main food strategy is rotational grazing, with daily picket exchanges while some properties use the native field as a forage source.

The area used for the production of silage and hay is $5.33 \pm 7.23$ ha, but only $39.47 \%$ of the farms produce corn silage, with a daily supply to the animals of $13.74 \mathrm{~kg}$, and $31.57 \%$ of the farms produce hay entirely of Cynodon sp (Tifton 85).

Considering the total dairy cattle from the MPUs, a mean of $69 \pm 61$ animals was obtained. However, it comprises a mean of $29 \pm 20$ lactating cows, $13 \pm 21$ dried cows, $14 \pm 16$ heifers, and $8 \pm 8$ calves. In the composition of the herds, the mean of animals in production is $47.64 \pm 12.64 \%$ while $32.64 \pm 10.40 \%$ corresponds to heifers or calves destined to the replenishment of the stock. The mean daily production observed was $518 \pm 423$ liters, with a mean yield of $8,445 \pm 5,425$ liters/hectare/year.

At milking, wooden or concrete stables are used, with concrete floors and milking parlor with a moat in $58 \%$ and $42 \%$ of the MPUs, respectively. The mechanical milking with bucket at the foot is carried out in $21.05 \%$ of the MPUs, and the channeled milking or with milk transfer in $78.95 \%$. All MPUs store and cool down the milk produced in expansion tanks. A similar reality was found in the northwest region of Santa Catarina (Costa et al., 2010), where $64 \%$ of the cattle farms performed milking with a bucket at the foot and only $36 \%$ of the them had milking parlor with a moat.

During the milk handling, only $23.68 \%$ of the MPUs adopt the correct milking sequence. The pre and post-dipping is performed in $63.16 \%$ of them, while $21.05 \%$ performed only post-dipping and $15.79 \%$ did not adopt any practices to disinfect the cow tits before milking. Mammary gland sanitary control through the California Mastitis Test (CMT) is performed in only $13.16 \%$ of the MPUs, while $36.84 \%$ perform the black bottom mug test. From the MPUs studied, $26.32 \%$ disregarded the first milk jets on the floor of the milking parlor to evaluate the physical characteristics of the milk, and $23.68 \%$ did not perform any tests before milking the animals. Regarding the hygiene of milking equipment, $74 \%$ of producers adopt adequate hygiene procedures of milking equipment with the use of specific detergents. All MPUs evaluated used tap water.

The multivariate analysis made it possible to reduce the variables (Table 1) of the study into two main components ( $\mathrm{CP} 1$ and $\mathrm{CP} 2$ ), which have eigenvalues greater than 1 (alpha $>1$ ) (Fraga et al., 2016) and together explain $55.05 \%$ of the variability of characteristics of the 38 MPUs of this study (Figure 1). Thus, the two main components effectively summarize the total sample variance and could be used to study the dataset (Hongyu et al., 2015).

The CP1 considers the productive capacity of the farms (TotAnim, LactCows, LactCowsPercCows, DryCowsPerCows, PercProdTotal and ProdHecYear), and factors related to the nutritional management (ArCropPerPast and SuppSil) of MPUs, directly interfering with reproductive performance (IBC) (Figure 1). CP2 is explained by milk handling (TypeMilk, Dipping, and MilkTest) and daily milk production (ProdDaily) of the farm. This last variable is directly affected by the number of animals (TotAnim and LactCows) of the MPUs.

CP1 denotes negative relation with type of concentrate (ConcType). In this study, several MPUs carried out the preparation of the concentrate that made up the animals' feed, often without technical guidance for cost reduction. This concentrate consisted mainly of corn meal, soybean, rice, and wheat bran as well as minerals. The absence of diet formulation contemplating the nutritional requirement of animals as well as the composition of their food has a direct impact on the dairy production. This represents a loss instead of the supposed reduction of costs with the nutritionist technician. Productive and financial loss due to improper use of feed in the animals' diet is a potential risk as producers are known to expend up to $30 \%$ of the gross milk income for concentrated herd feeding (OLIVEIRA et al., 2007; PEREIRA et al., 2016). In a study carried out to map the costs of a type B milk farm located in Vale do Taquari-RS, the cost of concentrate represented $45.66 \%$ of the gross milk income (EHRENBRINK; REHFELDT, 2016). 
Table 1. Numerical participation, mean $\pm \mathrm{SD}$, minimum (Min) and maximum (Max) of the variables in the main components 1 and 2 for groupings of milk production systems of the Northwest, Midwest and Southwest of Rio Grande do Sul.

\begin{tabular}{|c|c|c|c|c|c|c|}
\hline \multirow[t]{2}{*}{ Variables } & \multirow[t]{2}{*}{ Variable Description } & \multicolumn{2}{|c|}{$\begin{array}{c}\text { Main } \\
\text { Components }\end{array}$} & \multirow[t]{2}{*}{ Mean \pm SD } & \multirow[t]{2}{*}{ Min } & \multirow[t]{2}{*}{ Max } \\
\hline & & 1 & 2 & & & \\
\hline YearsActi & Years in the activity & $0.647^{*}$ & 0.252 & $19.3 \pm 13$ & 1 & 40 \\
\hline TotArea (ha) & Total farm area & -0.578 & 0.669 & $59.7 \pm 90$ & 9 & 476 \\
\hline ArCropPerPast (há) & Percentage of crop area pastures & 0.788 & 0.148 & $23.8 \pm 39$ & 2 & 82 \\
\hline ProdDaily (Liters) & Daily milk production in the farm & 0.217 & 0.840 & $519 \pm 423$ & 35 & 1,4 \\
\hline ProdHecYear (\%) & Productivity per hectare per year & 0.812 & 0.214 & $8,4 \pm 5,4$ & 1,6 & 22,2 \\
\hline TotAnim & Total cattle size in the farm & -0.152 & 0.882 & $69 \pm 61$ & 7 & 330 \\
\hline LactCows & Lactating cows in the farm & 0.027 & 0.898 & $30 \pm 21$ & 5 & 92 \\
\hline LactCowsPercCows (\%) & Lactating cows of the percentage of cows & 0.785 & 0.088 & $32.6 \pm 10$ & 18 & 71 \\
\hline DryCowsPerCows (\%) & Dry cows of the percentage of cows & 0.774 & 0.105 & $28 \pm 14$ & 5 & 57 \\
\hline PercProdTotal (\%) & Productive percentage of the herd & 0.778 & 0.017 & $47.6 \pm 14$ & 4 & 47 \\
\hline $\mathrm{IBC}^{1}$ & Intervals between calving of animals & 0.734 & -0.446 & $1.6 \pm 1$ & 1 & 2 \\
\hline SuppSil (Kg) & Silage supply to animals & 0.728 & 0.417 & $3.2 \pm 2$ & 1 & 6 \\
\hline TypeMilk $^{2}$ & Milking type in the farm & -0.431 & 0.676 & $3.2 \pm 1$ & 2 & 4 \\
\hline Dipping $^{3}$ & Dipping use & -0.311 & 0.757 & $3.1 \pm 1$ & 1 & 4 \\
\hline MilkTest $^{4}$ & Milking tests use & 0.366 & 0.595 & $3.2 \pm 2$ & 1 & 8 \\
\hline MastTime $^{5}$ & Time of mastitis & 0.844 & -0.363 & $2 \pm 0.8$ & 1 & 3 \\
\hline
\end{tabular}

* Measure of sampling adequacy (MSA) greater than or equal to 0.6 , by Bartlett Test. ${ }^{1}$ IBC: Intervals between calving of animals, $1(>12$ months), 2(<= 12 months); ${ }^{2}$ TypeMilk: Milking type in the farm, 2 (bucket on foot), 3(mechanized with protractor), 4(channeled); ${ }^{3}$ Dipping: Dipping use 1(no), 3(pre-dipping), 4(pre-dipping and post-dipping); ${ }^{4}$ MilkTest: Milking tests, 1(does not perform), 2(discard first milk jets only), 3(black background mug test), 4(CMT), 5(discard first milk jets and use black background mug); ${ }^{5}$ MastTime: Period of mastitis 1(dried), 2(wet), 3(dried and wet).

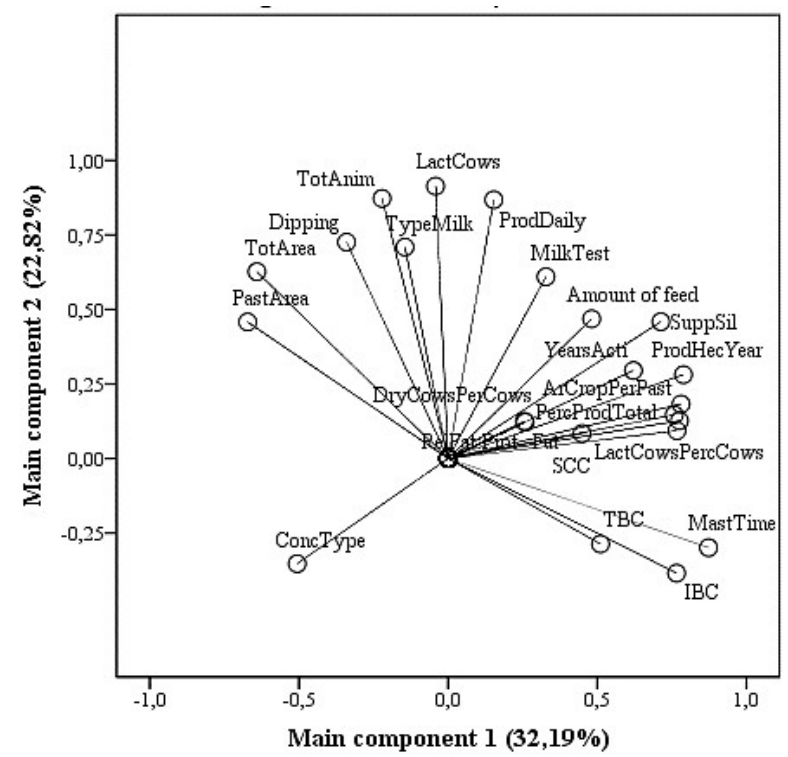

Figure 1. Contributions of the variables for the formation of the main components (CP) 1 and 2 of the milk production systems of the Northwest, Center Western and Southwest mesoregions of Rio Grande do Sul.

ConcType: Type of concentrate. PastArea: Pasture area. TypeMilk: Type of milking. TotArea: Total farm area. Dipping: Dipping use. TotAnim: Total of animals. ProdDaily: Daily production MilkTest: Milking type in the farm. AmountFeed: Amount of feed. OfferSil: Offer of silage. ProdHecYear: Productivity per hectare per year. ArCropPerPast: Percentage of crop area pastures. LactCowsPercCows: Lactating cows of the percentage of cows. RelFat:Prot: fat-protein ratio. Fat: Fat. SCC: Somatic cell count. PercProdTotal: Total productive percentage. TBC: Total bacterial count. IBC: Intervals between calving of animals. MastTime: Period of mastites. 
Milk production units...

In the productive evaluation of MPUs, there is a great influence of the variables that make up the productive capacity factor of the farms (Table 2). These variables showed significant correlations with the areas destined for food production (pastures and silages) and the number of animals that compose the herds, confirming their impact on the productive efficiency of the MPUs. In the milk activity, many MPUs seek to increase milk production only by increasing the number of animals, especially lactating cows (O’DRISCOLL et al., 2010). However, in order for this goal to be achieved, the number of animals and the food production capacity of the MPUs must be increased at the same time (KROLOW et al., 2012). These MPUs should seek
TADIELO, L. E. et al.

subsidies for the formation of pastures, which are allies of preserved foods and concentrates that meet the nutritional needs of the animals, guaranteeing their maintenance, production, and reproduction. Regarding this, there are MPUs that stand out in this study because they produce large scale fodder, serving for grazing and preserved products (silages, pre-dried, and hay), being in compliance with adequate nutrition of the herd and reflecting in high daily production. On the other side, there are MPUs where forage production is precarious. They often use the native field with low supply of dry matter and high stocking, mainly of spare animals (heifers and calves).

Table 2. Pearson's correlations among the main variables that characterize the structure of the farms (TotAnim, LactCows, LactCowsPercCows, and DryCowsPerCows), nutritional management (TotArea and ArCropPerPast), productivity of MPUs (ProdDaily and ProdHecYear), and experience in the activity (YearsActi) of the MPUs of the Northwest, Center Western and Southwest mesoregions of Rio Grande do Sul.

\begin{tabular}{lccccc}
\hline & ProdHecYear & TotAnim & LactCows & LactCowsPercCows & DryCowsPerCows \\
\hline YearsActi & $0.518^{* *}$ & $0.192^{*}$ & $0.339^{*}$ & $0.544^{* *}$ & $0.534^{* *}$ \\
TotArea & $-0.406^{*}$ & $0.697^{* *}$ & $0.634^{* *}$ & $-0.324^{*}$ & $-0.302^{*}$ \\
ArCropPerPast & $0.663^{* *}$ & $-0.031^{*}$ & $0.073^{*}$ & $0.533^{* *}$ & $0.515^{* *}$ \\
ProdDaily & $0.478^{*}$ & $0.853^{* *}$ & $0.910^{* *}$ & $0.191^{*}$ & $0.211^{*}$ \\
ProdHecYear & & $0.115^{* *}$ & $0.220^{*}$ & $0.606^{* *}$ & $0.607^{* *}$ \\
TotAnim & & & $0.931^{* *}$ & $-0.086^{*}$ & $-0.049^{*}$ \\
LactCows & & & & $0.051^{*}$ & $0.062^{*}$ \\
LactCowsPercCows & & & & & $0.987^{* *}$ \\
\hline
\end{tabular}

**;*: significant at 1 and at $5 \%$ of probability, respectively.

In the evaluation of $\mathrm{CP} 2$, there is a positive correlation between the type of milking, use of pre and post-dipping, daily production and number of lactating cows (Figure 1 and Table 3). However, there was an inverse relationship among the variables mentioned above and the total bacterial count and the period of occurrence of mastitis in cows. Thus, the adoption of the correct milk handling techniques and the use of pre and postdipping collaborate to reduce the occurrence of mastitis that is one of the critical factors for the increase of TBC. This aspect is relevant because if the farms adopt and follow correctly the recommended technologies for milk handling, an improvement in milk quality produced will be seen (NERO et al., 2009).

Other factors evaluated are the type of milking and its facilities. Peculiar characteristics attributed to these factors contribute to the effectiveness or not of the hygienic-sanitary conditions of the equipment and milking parlor. (PICOLI et al., 2014) observed that the type and location of milking and its facilities, along with the adoption of indicated practices for milk handling, collaborated for the occurrence of infectious agents in the milk. They explained that the inefficient milk handling and the poor facilities of the MPUs hinder the hygiene of the equipment, increasing the number of microorganisms that indicate poor hygiene quality, as well as favor the occurrence of mastitis in cows. 
Table 3. Correlations between the main variables that characterize milk handling (Dipping and MilkTest), structure (TypeMilk), and milk quality indicators (SCC, TBC, and Fat) of different production systems of the Northwest, Center Western and Southwest mesoregions of Rio Grande do Sul.

\begin{tabular}{lllllll}
\hline & Dipping & MilkTest & SCC & TBC & Fat & RelFat:Prot \\
\hline MastTime & $-0.636^{* *}$ & $-0.014^{*}$ & $0.349^{*}$ & $0.498^{*}$ & $0.202^{*}$ & $0.219^{*}$ \\
TypeMilk & $0.624^{* *}$ & $0.163^{*}$ & $-0.263^{*}$ & $-0.454^{*}$ & $-0.193^{*}$ & $-0219^{*}$ \\
Dipping & & $0.452^{* *}$ & $-0.071^{*}$ & $-0.398^{*}$ & $-0.12^{*}$ & $-0.14^{*}$ \\
MilkTest & & & $0.162^{*}$ & $0.059^{*}$ & $0.209^{*}$ & $0174^{*}$ \\
SCC & & & $0.475^{*}$ & $0.244^{*}$ & $0211^{*}$ \\
TBC & & & & $0.121^{*}$ & $0127^{*}$ \\
Fat & & & & & $0.976^{* *}$ \\
\hline
\end{tabular}

**;*: significant at 1 and at $5 \%$ of probability, respectively.

After finding out the main variables that characterize the milk production systems of the Northwest, Center Western and Southwest mesoregions of Rio Grande do Sul and their respectively weight, these variables were submitted to the Hierarchical Classification of Clusters. From this analysis, the data set generated from the 38 MPUs studied were adjusted and classified into five groups (G1, G2, G3, G4, and G5) (Figure 2 and Table 4).

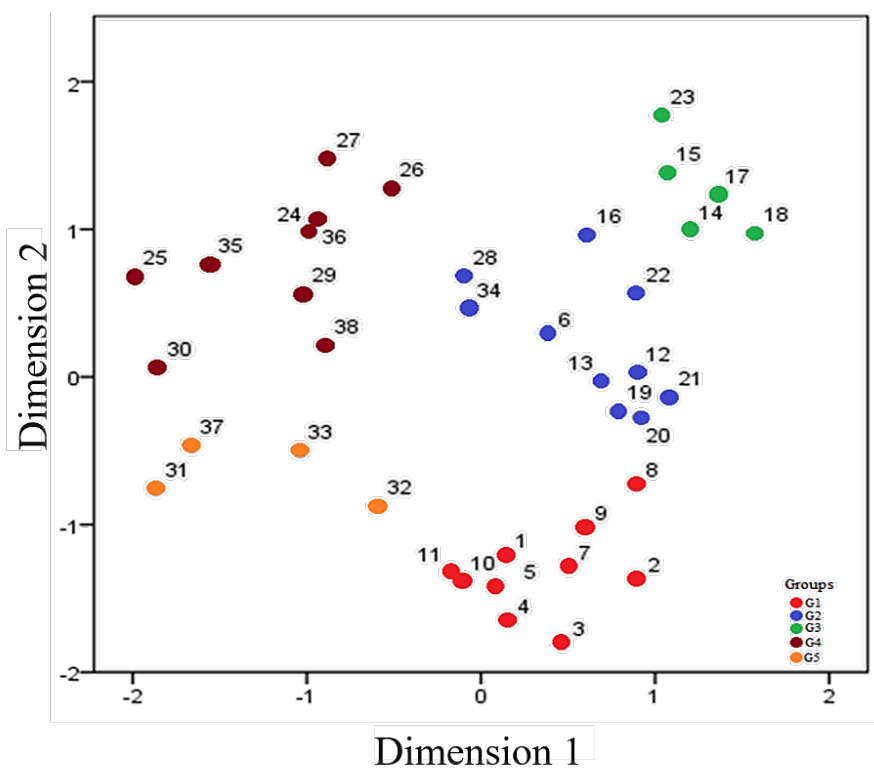

Figure 2. Representation of the clusters formed from the analysis of the main components of the UPLs of the Northwest, Center Western and Southwest mesoregions of Rio Grande do Sul.

The G1 group is composed of 10 MPUs that resemble low production (180 liters / day), fewer total and lactating animals, and not statistically different from G5 (Table 4). However, G1 presents good productivity in the year (3,651 liters / year), differing statistically from G3. G1 has a mechanized milking transfer system, but hygienic-sanitary milking conditions are poor. This contributes to the increase in TBC $(314 \times 1,000 \mathrm{CFU} / \mathrm{ml})$, which is at odds with the current percentages allowed by Normative Instruction 62 (IN 62) (BRAZIL, 2011). In addition, this production system may also interfere with milk production (Figure 1), reducing it. This group needs to pay special attention to proper milk handling, such as pre- and post-dipping and proper cleaning methods for milking equipment (alkaline and acidic solutions). This proper handling of milk will provide higher milk quality and consequently better system profitability. 
Table 4. Analysis of clusters with the main variables that make up the milk production systems of the Northwest, Center Western and Southwest mesoregions of Rio Grande do Sul.

\begin{tabular}{|c|c|c|c|c|c|c|c|}
\hline \multirow[b]{2}{*}{ Variables } & \multicolumn{5}{|c|}{ Clusters (Groups) } & \multirow[b]{2}{*}{ Mean } & \multirow{2}{*}{$\begin{array}{l}C V^{*} \\
(\%)\end{array}$} \\
\hline & $\begin{array}{c}\mathbf{1} \\
(\mathrm{n}=10)\end{array}$ & $\begin{array}{c}\mathbf{2} \\
(\mathrm{n}=10)\end{array}$ & $\begin{array}{c}3 \\
(\mathrm{n}=5)\end{array}$ & $\begin{array}{c}\mathbf{4} \\
(\mathrm{n}=9)\end{array}$ & $\begin{array}{c}\mathbf{5} \\
(\mathrm{n}=4)\end{array}$ & & \\
\hline YearsActi & $21.4 \mathrm{~b}$ & $19.3 \mathrm{~b}$ & $40.00 \mathrm{a}$ & $9.88 \mathrm{~b}$ & $9.25 b$ & 19,29 & 44,52 \\
\hline TotArea & $13.65 b$ & $25.95 b$ & $35.60 \mathrm{~b}$ & $170.22 \mathrm{a}$ & $40.25 b$ & 59,65 & 112,6 \\
\hline PastArPerc $^{1}$ & $5.80 \mathrm{a}$ & $4.60 \mathrm{a}$ & $3.60 \mathrm{a}$ & $5.55 \mathrm{a}$ & $4.25 \mathrm{a}$ & 4,97 & 51,47 \\
\hline ArCropPerPast ${ }^{2}$ & $3.20 \mathrm{abc}$ & $4.70 \mathrm{ab}$ & $6.00 \mathrm{a}$ & $1.55 \mathrm{bc}$ & $1.00 \mathrm{c}$ & 3.34 & 64.62 \\
\hline ProdDaily & $185.01 \mathrm{~d}$ & $507.50 \mathrm{bc}$ & $1056.01 \mathrm{a}$ & $664.44 \mathrm{ab}$ & $381.25 \mathrm{~cd}$ & 518.68 & 65.48 \\
\hline ProdHecYear $^{3}$ & $3651.50 \mathrm{bc}$ & $6402.30 \mathrm{~b}$ & $10571.01 \mathrm{a}$ & $1780.33 c$ & $1994.50 \mathrm{c}$ & 4668.26 & 51.68 \\
\hline TotAnim & $24.70 \mathrm{c}$ & $56.91 b c$ & $86.20 \mathrm{ab}$ & $126.89 a$ & $53.25 \mathrm{c}$ & 68.47 & 72.85 \\
\hline LactCows & $11.80 \mathrm{~b}$ & $28.20 \mathrm{ab}$ & $48.80 \mathrm{a}$ & $45.44 \mathrm{a}$ & $19.01 \mathrm{~b}$ & 29.7 & 52.1 \\
\hline PercProdTotal $^{4}$ & $50.90 \mathrm{ab}$ & $54.10 \mathrm{a}$ & $59.01 \mathrm{a}$ & $37.11 b c$ & $32.25 \mathrm{c}$ & 47.57 & 19.57 \\
\hline $\mathrm{IBC}^{5}$ & $2.10 \mathrm{a}$ & $1.70 \mathrm{a}$ & $1.80 \mathrm{a}$ & $1.00 \mathrm{~b}$ & $1.00 \mathrm{~b}$ & 1.57 & 21.49 \\
\hline SuppSil & $8.20 \mathrm{~b}$ & $22.90 \mathrm{a}$ & $29.00 \mathrm{a}$ & $6.88 \mathrm{~b}$ & $1.00 \mathrm{~b}$ & 13.74 & 58.72 \\
\hline ConcType $^{6}$ & $3.50 \mathrm{a}$ & $3.00 \mathrm{ab}$ & $2.20 \mathrm{~b}$ & $3.33 \mathrm{ab}$ & $4.00 \mathrm{a}$ & 3.21 & 25.02 \\
\hline AmountFeed & $2.70 \mathrm{c}$ & $5.70 \mathrm{ab}$ & $7.20 \mathrm{a}$ & $3.66 \mathrm{bc}$ & $4.25 \mathrm{bc}$ & 4.47 & 29.05 \\
\hline TypeMilk $^{7}$ & $2.70 \mathrm{a}$ & $2.90 \mathrm{ab}$ & $3.80 \mathrm{a}$ & $3.77 \mathrm{a}$ & $3.25 \mathrm{ab}$ & 3.21 & 20.36 \\
\hline Dipping $^{8}$ & $1.40 \mathrm{~b}$ & $3.20 \mathrm{a}$ & $4.00 \mathrm{a}$ & $4.00 \mathrm{a}$ & $4.00 \mathrm{a}$ & 3.1 & 19.42 \\
\hline MilkTest $^{9}$ & $1.40 \mathrm{c}$ & $5.20 \mathrm{a}$ & $4.60 \mathrm{ab}$ & $2.78 \mathrm{abc}$ & $2.25 \mathrm{bc}$ & 3.23 & 52 \\
\hline $\mathrm{SCC}^{10}$ & $902.50 \mathrm{a}$ & $1034.10 \mathrm{a}$ & $1036.80 \mathrm{a}$ & $762.11 \mathrm{a}$ & $469.50 \mathrm{a}$ & 875.97 & 79.41 \\
\hline $\mathrm{TBC}^{11}$ & $314.80 \mathrm{a}$ & $123.20 \mathrm{a}$ & $58.20 \mathrm{a}$ & $65.80 \mathrm{a}$ & $74.00 \mathrm{a}$ & 146.31 & 161.81 \\
\hline Fat $^{12}$ & $3.56 \mathrm{a}$ & $3.75 \mathrm{a}$ & $3.78 \mathrm{a}$ & $3.77 \mathrm{a}$ & $3.95 \mathrm{a}$ & 3.73 & 10.36 \\
\hline RelFat:Prot ${ }^{13}$ & $1.05 \mathrm{ab}$ & $0.83 b$ & $1.01 \mathrm{ab}$ & $1.95 \mathrm{ab}$ & $2.16 \mathrm{a}$ & 1.32 & 62.42 \\
\hline MastTime $^{14}$ & $2.70 \mathrm{a}$ & $1.80 \mathrm{~b}$ & $2.20 \mathrm{ab}$ & $1.00 \mathrm{c}$ & $1.00 \mathrm{c}$ & 1.81 & 20.34 \\
\hline
\end{tabular}

Median followed by same letters do not differ $(\mathrm{p}$-value $<0.05)$ by Tukey Test. ${ }^{1}$ PastArPerc: Pasture area of the percentage of the total area (ha), 3(21-30), 4(31-40), 5(41-50); ${ }^{2}$ ArCropPerPast: Percentage of crop (silage/hay) area pastures (ha), 1(0-10), 3(21-30), 4(30-50), 6(101-150); ${ }^{3}$ ProdHecYear: Productivity per hectare per year (liters/ha); ${ }^{4}$ PercProdTotal: Total productive percentage of the herd; ${ }^{5}$ IBC: Intervals between calving of animals, $1(>12$ months $), 2\left(<=12\right.$ months); ${ }^{6}$ ConcType: Concentrated type 2(prepared in farm), 3 (commercial+ prepared in farm), 4(commercial); ${ }^{7}$ TypeMilk: Milking type in the farm, 2 (bucket on foot), 3(mechanized with protractor), 4(channeled); ${ }^{8}$ Dipping: Dipping use 1(no), 3(pre dipping), 4(pre dipping and post dipping); ${ }^{9}$ MilkTest: Milking tests use, 1(does not perform), 2(discard jets only), 3(black background mug), 4(CMT), 5(discard jets and use black background mug); ${ }^{10} \mathrm{SCC}$ : somatic cell counts $(\mathrm{x} 1000 \mathrm{cell} / \mathrm{mL}) ;{ }^{11} \mathrm{TBC}$ : Total bacterial count $(\mathrm{x} 1000 \mathrm{cell} / \mathrm{mL}) .{ }^{12} \mathrm{Fat}: \mathrm{Fat}(\mathrm{g} / 100 \mathrm{~g}) ;{ }^{13}$ RelFat:Prot fat-protein ratio; ${ }^{14}$ MastTime: Period of mastitis 1 (dried), 2(wet), 3(dried and wet). ${ }^{*} \mathrm{CV}$ : coefficient of variation.

The G1 and G2 MPUs present hygienic and sanitary conditions for adequate milk production, such as: correct milking routine, pre and postdipping use, black bottom mug testing, cleaning and sanitization of milking equipment and utensils. However, the MPUs of the G2 and G3 groups reported higher incidence of mastitis in the wet seasons (winter and spring). This can be observed by the high SCC $(1,034.10 \times 1000$ cells $/ \mathrm{ml}$; $1,036.80 \times 1000$ cells $/ \mathrm{ml})$ and TBC $(58.20 \times 1000$ $\mathrm{CFU} / \mathrm{ml} ; 123.20 \times 1000 \mathrm{CFU} / \mathrm{ml})$ in the $\mathrm{G} 2$ and $\mathrm{G} 3$ groups, respectively. These results can be explained by twofold: the occurrence of mastitis caused by environmental pathogens (BOBBO et al., 2017), mainly from the high amount of organic matter, and the high productivity of the animals. The high production of cows weakens their immune system making it harder for their bodies to combat the health challenges that they are exposed to (GABBI et al., 2016). These two groups have units that adopt suitable technologies for the nutrition of their cattle. They use a significant fraction of the farm area to produce bulky food. In addition, through the use of forage species and a good management, the units in G2 and G3 groups are able to provide sufficient quantity and quality of pasture, silage, and hay.

The G4 group presents MPUs with large areas, but they allocate little area for fodder purposes. This has a great connection with the low productivity $(1,780.33$ liters/year) which is related to the small productive (lactating and dried cows) portion of the cattle $(37.11 \%)$. On the other side, the number of heifers and calves is high, so resulting in a significant number of animals (127 animals/farm). 
This group comprises MPUs that are increasing the cattle; therefore tend to increase the daily production in the future. However, the MPUs from this group need technical assistance with regard to the nutrition of the animals.

The G5 had MPUs characterized by the low technological level used in animal nutrition. They only used $10 \%$ of the pasture area for silage production, and they did not supply hay to the animals. These MPUs had a small productive portion of the cattle, with few lactating cows and low daily production (381.25 liters/day). Regarding the reproductive approach, the interval between calving of animals is greater than 12 months. This is easily explained by the lack of nutrition of the cattle, which did not statistically differ from the G4 group.

\section{CONCLUSIONS}

There is a wide variation between infrastructure and nutritional management among the MPUs studied, and this demonstrates the need for greater technical incentive in the regions.

The productivity of MPUs is directly influenced by the nutrition attributed to the animals. Proper hygienic-sanitary management of milk is closely linked to milk quality as well as farm productivity.

The use of qualitative and quantitative screening tests are of great importance for the effectiveness of the process. As well as, further studies are needed to evaluate and correlate the economic and social relationship of dairy farmers in these regions, aiming at greater profitability of the production process.

RESUMO: Avaliar e caracterizar sistemas de produção utilizando as características das propriedades permite diagnosticar os pontos falhos, visando melhorar os índices produtivos e zootécnicos, desse modo pouco se sabe sobre os sistemas de produção de leite no estado do Rio Grande do Sul. Assim, objetivou-se com este estudo caracterizar os sistemas de produção de leite das mesorregiões Noroeste, Centro-Oeste e Sudoeste do Rio Grande do Sul, considerando a infra-estrutura, a quantidade, qualidade e composição do leite e o manejo nutricional dos rebanhos. Para conduzir este estudo, 38 Unidades de Produção de Leite (UPLs) registradas nas Secretarias Municipais de Agricultura e Emater/Ascar-RS foram selecionadas aleatoriamente. Depois, as fazendas leiteiras foram visitadas, um questionário semi-estruturado foi aplicado e amostras de leite do tanque foram coletadas. $\mathrm{O}$ leite foi analisado quanto à contagem de células somáticas (CCS) e à contagem bacteriana total (CBT). Os dados foram avaliados através de análise de componentes principais e análise de cluster. A análise multivariada permitiu que as variáveis investigadas fossem reduzidas em dois componentes principais (CP1 e CP2). Estes apresentaram autovalores maiores que 1 (alfa $>1)$ e juntos explicaram 55,05\% da variabilidade das características das 38 UPLs estudadas. O CP1 contemplou a capacidade produtiva e os fatores relacionados ao manejo nutricional das UPLs, interferindo diretamente no desempenho produtivo. CP2 compreendeu manipulação de leite e produção diária. Utilizando essas variáveis principais, os dados gerados a partir das 38 UPLs estudadas foram ajustados e estas classificadas em cinco grupos (G1, G2, G3, G4 e G5). As características desses grupos diferiram estatisticamente, especialmente em infraestrutura e manejo nutricional do rebanho. Devido a suas particularidades, cada um desses cinco grupos de MPUs requer intervenções técnicas estratégicas para melhorar seus índices produtivos.

PALAVRAS-CHAVE: Gestão. Sistemas de Produção. Qualidade do Leite.

\section{REFERENCES}

AGOSTINHO F.A.; OLIVEIRA M.W.; PULSELLI F.M.; ALMEIDA C.M.V.B.; GIANNETTI B.F. Emergy accounting as a support for a strategic planning towards a regional sustainable milk production. Agricultural Systems, v. 176, p. 102-106, 2019. https://doi.org/10.1016/j.agsy.2019.102647

ALVARES, C. A.; STAPE, J. L.; SENTELHAS, P. C.; DE MORAES, G.; LEONARDO, J.; SPAROVEK, G. Köppen's climate classification map for Brazil. Meteorologische Zeitschrift, Stuttgart, v. 22, n. 6, p. 711-728, dec., 2013. https://doi.org/10.1127/0941-2948/2013/0507

BANKUTI, F. I.; CALDAS, M.M. Geographical milk redistribution in Paraná State, Brazil: Consequences of institutional and market changes. Journal of Rural Studies, v. 64, p. 63-72, 2018.

https://doi.org/10.1016/j.jrurstud.2018.10.004 
BOBBO, T.; RUEGG, P. L.; STOCCO, G.; FIORE, E.; GIANESELLA, M.; MORGANTE, M.; PASOTTO, D.; BITTANTE, G.; CECCHINATO, A. Associations between pathogen-specific cases of subclinical mastitis and milk yield, quality, protein composition, and cheese-making traits in dairy cows. Journal of Dairy Science, Champaign, v. 100, n. 6, p. 4868-4883, jun, 2017. https://doi.org/10.3168/jds.2016-12353

BODENMÜLLER FILHO, A.; DAMASCENO, J. C.; PREVIDELLI, I. T. S.; SANTANA, R. G.; RAMOS, C. E. C. d. O.; SANTOS, G. T. d. Tipologia de sistemas de produção baseada nas características do leite. Revista Brasileira de Zootecnia, Viçosa, v. 39, n. 8, p. 1832-1839, aug., 2010. https://doi.org/10.1590/S151635982010000800028

BRASIL. Instrução Normativa $n^{\circ}$ 62, de 29 de dezembro de 2011. Regulamento técnico de identidade e Qualidade do Leite Cru Refrigerado. Ministério da Agricultura e Abastecimento, 9. Diário Oficial da União: Diário Oficial da União,13-14, 1, 2011.

COSTA, R. G.; DAL MONTE, H. L. B.; PIMENTA FILHO, E. C.; HOLANDA JÚNIOR, E. V.; CRUZ, G. R. B. d.; MENEZES, M. P. C. Typology and characterization of goat milk production systems in the Cariris Paraibanos. Revista Brasileira de Zootecnia, Viçosa, v. 39, n. 3, p. 656-666, mar., 2010. https://doi.org/10.1590/S1516-35982010000300027

EHRENBRINK, C. F.; REHFELDT, M. J. H. Mapeamento de custos e receitas da produção de leite em uma propriedade rural do Vale do Taquari. Revista Estudo \& Debate, Lajeado, v. 23, n. 1, p. 70-96, jan./jun., 2016.

FRAGA, A. B.; DE LIMA SILVA, F.; HONGYU, K.; DA SILVA SANTOS, D.; MURPHY, T. W.; LOPES, F. B. Multivariate analysis to evaluate genetic groups and production traits of crossbred Holstein $\mathrm{x}$ Zebu cows.

Tropical animal health and production, Edinburgh, v. 48, n. 3, p. 533-538, mar, 2016.

https://doi.org/10.1007/s11250-015-0985-2

GABBI, A. M.; MCMANUS, C. M.; ZANELA, M. B.; STUMPF, M. T.; BARBOSA, R. S.; FRUSCALSO, V.; THALER NETO, A.; SCHMIDT, F. A.; FISCHER, V. Milk traits of lactating cows submitted to feed restriction. Tropical animal health and production, Edinburgh, v. 48, n. 1, p. 37-43, jan., 2016. https://doi.org/10.1007/s11250-015-0916-2

GABBI, A. M.; McManus, C.M.; SILVA, L. T.; MARQUES, M.B.; STUMPF, M.P.; FISCHER, V. Typology and physical-chemical characterization of bovine milk produced with different productions strategies.

Agricultural Systems, v. 121, p. 130-134, 2013. https://doi.org/10.1016/j.agsy.2013.07.004

HAIR, F. J.; BLACK, W. C.; BABIN, B.; ANDERSON, R. E.; TATHAN, R. L. Análise multivariada de dados. 6. ed. Porto Alegre: Bookman, 2009. 688 p.

HONGYU, K.; SANDANIELO, V. L. M.; OLIVEIRA JUNIOR, G. J. d. Principal Component Analysis: theory, interpretations and applications. E\&S - Engineering and Science, Cuiaba, v. 5, n. 1, p. 83-90, jan., 2015. https://doi.org/10.18607/ES201653398

IBGE, Instituto Brasileiro de Geografia e Estatística. Produção agropecuária (Ministério do Planejamento, Orçamento e Gestão). < https://www.ibge.gov.br/> 2014. Acessed on: 14/05/2017.

KROLOW, R. H.; SILVA, M. A.; PAIM, N. R.; MEDEIROS, R. B.; GONZALEZ, H. L. Composição do leite de vacas Holandesas em pastejo de azevém com a utilização do trevo branco como fonte proteica. Arquivo Brasileiro de Medicina Veterinária e Zootecnia, v. 64, n. 5, p. 1352-1359, nov./dec., 2012. https://doi.org/10.1590/S0102-09352012000500036 
LOPES JUNIOR, J. F.; CRISPIM DE OLIVEIRA RAMOS, C. E.; TADEU DOS SANTOS, G.; GRANDE, P. A.; DAMASCENO, J. C.; MASSUDA, E. M. Análise das práticas de produtores em sistemas de produção leiteiros e seus resultados na produção e qualidade do leite. Semina: Ciências Agrárias, Londrina, v. 33, n. 3, p. 1199-1208, mai/jun., 2012. https://doi.org/10.5433/1679-0359.2012v33n3p1199

MOURA, J. F. P. d.; PIMENTA FILHO, E. C.; GONZAGA NETO, S.; CÂNDIDO, E. P. Avaliação tecnológica dos sistemas de produção de leite bovino no Cariri da Paraíba. Revista Brasileira de Saúde e Produção Animal, Salvador, v. 14, n. 1, p. 121-131, jan./mar., 2013. https://doi.org/10.1590/S151999402013000100013

NERO, L. A.; VIÇOSA, G. N.; PEREIRA, F. E. V. Qualidade microbiológica do leite determinada por características de produção. Food Science and Technology, Campinas, v. 29, n. 2, p. 386-390, apr./jun., 2009. https://doi.org/10.1590/S0101-20612009000200024

O’DRISCOLL, K.; O’BRIEN, B.; GLEESON, D.; BOYLE, L. Milking frequency and nutritional level affect grazing behaviour of dairy cows: A case study. Applied Animal Behaviour Science, Amsterdam, v. 122, n. 2 , p. 77-83, jan., 2010. https://doi.org/10.1016/j.applanim.2009.11.014

OLIVEIRA, A. S. d.; CUNHA, D. d. N. F. V. d.; CAMPOS, J. M. d. S.; VALE, S. M. L. R. d.; ASSIS, A. J. d. Identificação e quantificação de indicadores-referência de sistemas de produção de leite. Revista Brasileira de Zootecnia, Viçosa, v. 36, n. 2, p. 507-516, mar./apr., 2007. https://doi.org/10.1590/S1516-35982007000200030

OLIVIO, C.J.; BECK, L.I.; GABBI, A.M.; CHARÃO, P. S.; SOBCZACK, M.F.; UBERTY, L.F.G.; DURR, J.W.; ARAÚJO FILHO, R. Composição e contagem de células somáticas do leite em fazendas convencionais e agroecológicas: um estudo comparativo na Depressão Central, Rio Grande do Sul, Brasil. Pesquisa Pecuária para o Desenvolvimento Rural, v. 17, n. 6, 2005.

PEREIRA, M. N.; RESENDE, J. C.; PEREIRA, R. A. N.; SILVA, H. C. M. Indicadores de desempenho de fazendas leiteiras de Minas Gerais. Arquivo Brasileiro de Medicina Veterinária e Zootecnia, Belo Horizonte, v. 68, n. 4, p. 1033-1042, apr., 2016. https://doi.org/10.1590/1678-4162-8218

PICOLI, T.; ZANI, J. L.; DA SILVA BANDEIRA, F.; BÜTTOW ROLL, V. F.; ROCHA RIBEIRO, M. E.; D’ÁVILA VARGAS, G.; OLIVEIRA HÜBNER, S.; DE LIMA, M.; ARAÚJO MEIRELES, M. C.; FISCHER, G. Manejo de ordenha como fator de risco na ocorrência de microorganismos em leite cru. Semina: Ciências Agrárias, Londrina, v. 35, n. 4, p. 2471-2480, apr., 2014. https://doi.org/10.5433/16790359.2014v35n4Suplp2471

PORTELA NUNES, J.; VIÉGAS, J.; NEUMANN SELVINO, P.; NETO SILVA, B.; LAURENTINO DIAS, L. Análise econômica de sistemas de produção com bovinocultura de leite da depressão central do Rio Grande do Sul. Ciência Rural, Santa Maria, v. 32, n. 5, p. 855-861, mai., 2002. https://doi.org/10.1590/S010384782002000500018

STANDARD, I. I. Milk and milk products - Determination of furosine content - Ion-pair reversephase high-performance liquid chromatography method. 17. ed. First: First, Addis Abada, 2004. 16 p.

WILLERS, C. D.; FERRAZ, S. P.; CARVALHO, L. S.; RODRIGUES, L. B. Determination of indirect water consumption and suggestions for cleaner production initiatives for the milk-producing sector in a Brazilian middle-sized dairy farming. Journal of cleaner production, Oxford, v. 72, n. 1, p. 146-152, jun., 2014. https://doi.org/10.1016/j.jclepro.2014.02.055

WINCK, C. A.; THALER NETO, A. Perfil de propriedades leiteiras de Santa Catarina em relação à Instrução Normativa 51. Revista Brasileira de Saúde e Produção Animal, Salvador, v. 13, n. 2, p. 296-305, fev., 2012. https://doi.org/10.1590/S1519-99402012000200001 